\title{
Liberating Oppressors: The Toughest Task of Full Reconciliation
}

\author{
R. Zachary Karanovich \\ Boston College School of Theology and Ministry (Brighton, MA)
}

\begin{abstract}
The process of reconciliation is necessarily centered on the victim. But Jürgen Moltmann rightly states that, "Oppression always has two sides." Insofar as one can envision the tasks of liberation and reconciliation to be at least parallel, a premise that this paper acknowledges, then liberation too must be forward thinking. To redeem the past, Moltmann argued that we must not only seek the liberation of the oppressed, but also the liberation of the oppressor. The preferential option for the victim is indeed necessary, but so too is the transformation of the oppressor. While this application of liberation on the side of the oppressor is not always warmly received by liberation thinkers, Jon Sobrino also stated the need for a continued openness to the oppressor as essential to reconciliation and the liberation spirituality. This paper will draw on theological, literary, and historical sources as well as current events to explore the status of this sometimes controversial question of the liberation of the oppressor and its place within the goal of reconciliation.
\end{abstract}

\section{Text}

"You have heard that it was said, 'You shall love your neighbor and hate your enemy.' But I say to you, love your enemies, and pray for those who persecute you" (Mt 5:43-45). I begin with this quote from Jesus's Sermon on the Mount for a couple of reasons. First, it is an attempt to at least begin to reframe how we understand ourselves. Jesus gives us two categories of people: neighbor and enemy. Then he blurs the distinction in his command that we are to love neighbor and enemy alike. I invite you to recall geometry class and equate neighbors with rectangles and enemies with squares: "An enemy is always a neighbor, but a neighbor is not always an enemy." Juvenile? Maybe. Trivial? No. Jesus is calling attention to his listeners' - our-mutating roles. Sometimes we are just the neighbor, but sometimes we are also the enemy.

The second reason I call attention to this passage is for the demands being made upon us. We easily fall prey to hating our enemies. Separating the "sin" from the "sinner" is a noble endeavor, but there are people who just make my skin 
crawl. With a viewpoint like that, my desire is not for their conversion and a friendship to develop, it is, instead, a desire for them to go away to the farthest reaches of the planet and live out their days with no impact on mine. Jesus, however, demands love.

The call to love in the context of Jesus's life and teaching is not a love of distant charitable concern, but an active restoration of the alienation between persons and their "enemies." Love is the call to reconciliation. Reconciliation is not, however, a unilateral activity completed by the half-hearted "I'm sorry," followed by the expectation that all will be well. Nor is it only - though not simply - the forgiveness granted to the offender by the victim without the request for the offender's conversion of life, to "go and sin no more." Full reconciliation is a transformation of a damaged relationship between individuals or groups that looks backward, to understand the reality of the offense, its causes, and the damage, and forward, to understand what needs to be done to ensure not just that one does not reoffend, but also that the proper attempts to bring good from evil occur. Full reconciliation, as just described, is inextricable from the process of full liberation.

With this parallel in mind, just as liberation theology's central principle is the "preferential option for the poor or oppressed," reconciliation's focus is on the victim as well. But that focus does not negate the bigger task of full reconciliation or liberation, which is to transform the relationship, requiring the oppressor's liberation.

This paper seeks to explore within reconciliation the liberation of the oppressor. In the first part, I will briefly explore the parallels between reconciliation and liberation, primarily as a way to highlight the framework of assumptions upon which I am exploring the larger question. In part two, I will look to the liberation of the oppressor as it was developed in the work of Jürgen Moltmann, one of the concept's more prominent advocates. In the third part, I will develop more clearly who it is I envision the oppressor to be within this framework. Finally, part four will look at the benefits and limitations of Moltmann's handling of the concept with reference to the particular oppressor I describe in part two.

This analysis does not end the conversation, however. The limitations inherent in a paper of this size do not permit an adequate exploration of the legitimate concerns with what a reconciled victim-offender relationship would look like, the power struggles within such a relationship that might exacerbate any trauma, or other problems that could arise from blind sympathy toward an offender-oppressor without adequate concern for the ongoing benefit of the victim(s). Instead, this paper focuses on a particular slice of oppression with an eye toward shining a different light in the hope of catching even a glimpse of a solution. With those limitations in mind, we move forward. 


\section{KARANOVICH: LIBERATING OPPRESSORS}

\section{Reconciliation as Liberation}

As noted above, I see the relationship between reconciliation and liberation to be inextricable. In an effort to avoid turning this paper into a theology of reconciliation qua reconciliation, I will below discuss a few interrelated points: the explicit relationship of reconciliation and liberation, the backward-looking aspect of reconciliation, and the forward-looking aspect of reconciliation.

Reconciliation presupposes an alienation from God, from neighbor, and from our true selves. But reconciliation is not "overcoming alienation for the sake of returning to [a prior status]," as Robert Schreiter explains. " "Christian reconciliation never takes us back to where we were before. It is more than the removal of suffering for the victim and conversion for the oppressor. Reconciliation takes us to a new place." 2 Schreiter - aware that reconciliation, like grace, is always available to us, but must be openly and consciously appropriated in the organic and ongoing reconciliation process - sees reconciliation, instead, as the "discovery of humanity in a new way" for both the victim and the oppressor. ${ }^{3}$

If reconciliation is the restoration of community through the discovery of the new way of humanity, then liberation "is not an alternative to reconciliation; it is the prerequisite for it." As Schreiter notes, liberation is what allows reconciliation to be peace and not merely truce. ${ }^{5}$ To achieve liberative reconciliation, a look backward is necessary. "Genuine reconciliation must meet conflict and face its causes squarely." 6

Insight into the backward-facing aspect can be found in the literature of restorative justice. "If we are to truly address harms and causes, we must explore the harms that those who cause harm have themselves experienced." 7 This analysis of the offender as a victim is important for the relationship between the backwardlooking and forward-looking aspects in the context of liberative reconciliation. "A perception of [the offender or oppressor] as a victim does not absolve responsibility for offending behavior. However ... we cannot expect offending behavior to stop without addressing the sense of victimization." ${ }^{8}$ To address the causes in this way also facilitates the discovery of the new humanity Schreiter described. "[W]hat truly vindicates [or liberates and reconciles] is acknowledgment of a victim's harms

1. Robert J. Schreiter, Reconciliation: Mission and Ministry in a Changing Social Order (Maryknoll, NY: Orbis Books, 1992), 55.

2. Schreiter, 55-56.

3. Schreiter, 56.

4. Schreiter, 22.

5. Schreiter, 23.

6. Schreiter, 24.

7. Howard Zehr, The Little Book of Restorative Justice, Revised and Updated (New York: Good Books, 2015), 41.

8. Zehr, 41. 


\section{KARANOVICH: LIBERATING OPPRESSORS}

and needs, combined with an active effort to encourage the offender to take responsibility, make right the wrongs, and address the causes of his or her behavior. By addressing this need for vindication in a positive way, [it] has the potential to affirm all parties and to help them transform their lives."9

With the assistance of restorative justice theory, reconciliation requires that even within a victim-oriented system, a focus on the offender-oppressor is necessary, with a particular concern for victimized offenders, or, as they will be called below, "oppressed oppressors."

\section{Moltmann's Liberation of the Oppressor}

Jürgen Moltmann was influenced by liberation theologians from many contexts-Latin American, black, feminist, and the likes. He became one of the most vocal advocates for an explicit liberation of the oppressor. He perceived it as the necessary response complimentary to liberation theologies by the "white, male, affluent Christians of the Northern hemisphere."10

He recognized, "Oppression always has two sides... [and] destroys humanity on both sides... The evil the perpetrator commits robs him of his humanity, the suffering he inflicts dehumanizes the victim." 11 In an attempt to address this concern and in light of the preferential option for the poor and oppressed advanced by liberation theology that was surfacing during the 1970s, Moltmann was not denying the primacy of the liberation of the oppressed, but rather acknowledging that "to help the oppressed gain their freedom we have to begin with ourselves by ceasing to be their oppressors." 12

Moltmann understands the process of liberating the oppressed and the oppressor as a multifaceted, simultaneously-occurring process involving the oppressed and oppressor alike. ${ }^{13}$ On the side of the oppressed, there is an active and a passive role to play. Actively, Moltmann describes the process as the oppressed "cut[ting] themselves off from their oppressors, so as to find themselves and their own humanity."14 In essence, it requires either the destruction of the relevant system of oppression - a task of obviously varying degrees, depending on the circum-

9. Zehr, 75.

10. Jürgen Moltmann and M. Douglas Meeks, "The Liberation of Oppressors," Christianity and Crisis (Dec. 1978): 311, understanding these descriptors as the most common traits of oppressors, historically.

11. Jürgen Moltmann, Experiences in Theology: Ways and Forms of Christian Theology (Minneapolis, MN: Fortress Press, 2000), 185.

12. Moltmann and Meeks, "The Liberation of Oppressors," 311.

13. Moltmann and Meeks, 310.

14. Moltmann, Experiences in Theology: Ways and Forms of Christian Theology, 186. 
stances - or the removal of themselves from such a system. Passively, the oppressed function as a witness to their suffering and, in so doing, encourage the conversion of the oppressor; the oppressor's "humanization." 15

On the side of the oppressor, the responsibility is for the oppressor to be open to conversion, or to "discover[] himself or herself in the crucified Jesus"-as the suffering of the oppressed witnesses to - and from that conversion, take up the cross of Christ, die to the old self of oppression, and rise to the new self of solidarity. ${ }^{16}$ Solidarity requires the post-conversion, rehabilitated oppressor to become a "stranger to their own people," and to take on the evangelistic discipleship of Christ for other oppressors. ${ }^{17}$

For Moltmann, the whole process requires the initiative of the oppressed along with those already in solidarity with them. The central, guiding role of the oppressed in full liberation is echoed by Paulo Freire. "This, then, is the great humanistic and historical task of the oppressed: to liberate themselves and their oppressors as well." 18 Freire and Moltmann would agree that the process of full liberation relies on God as evidenced by the weakest. "Only power that springs from the weakness of the oppressed will be sufficiently strong to free both." 19

One final point is important for understanding the consequences of Moltmann's perspective. Like Augustine and Rahner, Moltmann understands the root of oppression to be misplaced love. Instead of being fulfilled by the knowledge of the love of God within them, the oppressor seeks out love from elsewhere "which is directed away from [God from which] arises an unquenchable and therefore alldestructive passion: the mania of domination and the greed of possession." ${ }^{20}$ But Moltmann sees this to be almost beyond our control and linked, instead, to our concupiscence; "the sinner has lost his or her freedom." ${ }^{21}$ As a result, the moral appeal is inadequate to change the oppressor, who instead requires the conversion experience described above. ${ }^{22}$

\section{A Closer Assessment of the Oppressed Oppressor}

The image of the oppressor Moltmann advances is one who can easily acknowledge and change their situation, limited only by their sinfulness. If the analysis ends there, I might agree with Moltmann without reservation. But oppressors are more complex. In my evaluation, one of the shortcomings of Moltmann's

15. Moltmann and Meeks, "The Liberation of Oppressors," 315.

16. Moltmann and Meeks, 315-16.

17. Moltmann and Meeks, 316.

18. Paulo Freire, Pedagogy of the Oppressed, rev. ed. (New York: Continuum, 1993), 26.

19. Freire, 26.

20. Moltmann and Meeks, "The Liberation of Oppressors," 314.

21. Moltmann and Meeks, 314-15.

22. Moltmann and Meeks, 315. 


\section{KARANOVICH: LIBERATING OPPRESSORS}

ideas - and a place I believe his liberation of the oppressor would be best focusedis his inadequate handling of a category he uses only in passing: "oppressed oppressors." 23 While his assertion that many oppressors are operating blindly and "fail to see the suffering they inflict on their victims," 24 as well as his reliance on the sinner's action being by "compulsion," 25 hints toward real oppressed oppressors, I do not see his assessment as adequately addressing those I would consider in that category.

Oppression is a scale. On one end are individuals who are oppressors, and on the other end are individuals who are oppressed. Most fall somewhere in the middle, sometimes oppressing and sometimes oppressed, often simultaneously.

In order to avoid falling into the trap of seeing everyone as an oppressed oppressor and therefore no one, some distinction has to be drawn. I will admit, this is still an evolving line of thought for me - who the real oppressed oppressors areso I will limit this exploration to a group of individuals that I believe fall clearly within this category.

If one only reads the first five chapters of Howard Zinn's A People's History of the United States, the reader is presented with a core narrative that has been replaying since the founding of this country and reflects the trend going back since the development of society itself. The narrative is of an elite and powerful class that controls most of the resources of any division of society (the world, a country, a community), and, to protect their interests against the overwhelming majority of people who are not elite, they grant just enough power to one sub-set of the masses to enforce "law and order," ensuring the protection of the elite's property and power. ${ }^{26}$ In this model, those attempting to maintain power and wealth are the obvious oppressors, plain and simple. But those given the task of enforcing law and order - the "bureaucrats," of sorts - are those I would consider the oppressed oppressor.

The position of the oppressed oppressors is unique because the reality underlying the oppressive practices they partake in has been co-opted by the ultimate oppressors and reframed as good, at best, or value neutral, at worst. It is a form of educational oppression. For example, on a large scale, the mass incarceration of people of color, primarily men, rooted in the War on Drugs is the co-opting of the underlying reality - poverty, economic desperation, and addiction-for a seemingly good goal: to protect people from the consequences of drug use. ${ }^{27}$ The

23. Moltmann and Meeks, 311.

24. Moltmann, Experiences in Theology: Ways and Forms of Christian Theology, 186.

25. Moltmann and Meeks, "The Liberation of Oppressors," 315.

26. Howard Zinn, A People's History of the United States: 1492-Present (New York: Perennial Classics, 2003).

27. See Michelle Alexander, The New Jim Crow: Mass Incarceration in the Age of Colorblindness (New York: The New Press, 2010), 173-208. 
enforcers of this War on Drugs are likely unaware of the racism at the core of its initiative and, instead, probably believe their participation is good. In this case, the oppressor is an oppressor in action, not in intention.

A more current example is the way protests against racism have been coopted. There are many good-hearted people who believe that the NFL protests are misplaced and disrespectful to the members of the armed forces, regardless of whether they believe that racial injustices are actually a problem or not. As a matter of fact, there seems to be a growing number of individuals who see a racism problem, but still exacerbate it by demonizing those who use their platform to draw attention to the injustice.

Social media presents a unique aspect of the problem. It is easy for one to "Like" and "Share" a post that is seemingly innocuous_ "I Stand for the Flag and Kneel for the Cross"- but that perpetuates a bias against anyone who might use a certain protest tactic and silences their otherwise worthy concerns. This is the face of the "double identity" of America, according to Rosemary Radford Reuther, that includes "the ideology of God and love, peace and law, democracy and freedom," on the one hand, and its "evil twin that is concealed behind this rhetoric of positive national values and beliefs," on the other hand. ${ }^{28}$

Racists are the oppressor. Those that intentionally co-opt the reality of injustice and redirect attention from it are the oppressor. Those that create the meme are the oppressor. They not only oppress those on the far oppressed end of the oppression spectrum, but they also oppress those closer to the middle. Through educational, psychological, economic, and social oppression, the oppressor dehumanizes a sub-set of people to further their oppressive goals by way of seemingly beneficial projects rooted in "positive national values." This sub-set is the oppressed oppressor. ${ }^{29}$

\section{Liberation of the Oppressed Oppressor}

Taking a longer look at who constitutes the oppressed oppressor is no attempt to draw an equivalence to the victim-oppressed who requires the liberator's (and God's!) preferential option. My goal is not to reframe the preferential option in any way - a complaint that could possibly be raised against Moltmann. Instead, my goal is threefold: first, to challenge the notion that the liberation of the oppressor is some automatic outcome of the liberation of the oppressed; second, to clarify Moltmann's liberation of the oppressed from what some may interpret as an assault on the oppressed by an apparent raising up of the needs of the oppressed oppressor;

28. Rosemary Radford Reuther, America, Amerikkka (Oakville, C.T.: Equinox, 2007), 1.

29. For a very informative history of the way in which the poor and middle-class whites of the United States have been historically instrumentalized for injustice, see Nancy Isenberg, White Trash: The 400-Year Untold History of Class in America (New York: Penguin Books, 2016). 
and finally, to situate more clearly the liberation of the oppressor as a necessary element within liberative reconciliation. Because these points are intricately connected and have been made in part above, I will forego a point-by-point analysis of these goals and instead undertake a broader and briefer analysis that speaks to each in a more overlapping way.

The challenge of oppression that this paper focuses on is not a clear oppressor-oppressed situation with an explicit oppression tactic (think slavery). Rather, the oppression I have attempted to illustrate is one in which there is an oppressor and an oppressed, but many intermediate oppressed oppressors who are acting in good faith toward seemingly good goals. By no means new, it is a growing problem in a "post-truth" world in which we are inundated with "alternative facts." In some sense, the oppression is a particular evil masked by a timeless good. Whether it is slavery, Jim Crow, or the New Jim Crow, the mask will always look nice: law and order, peace, positive national values, and the likes. As such, the liberation of the oppressor is not a natural conclusion to the liberation of the oppressed because the mask never leaves. Those values will remain. Instead, the liberation of the oppressor is an ongoing process of humanization that leads to solidarity - a conversion of the oppressor - that is always on guard against the misuse of values in oppressing for exclusion and gain.

By no means does this undervalue the preferential option of the victim-oppressed. Instead, it seeks to truly liberate the victim-oppressed by addressing the root causes of oppression, but recognizes that such a task is no longer the mere ousting of a militant regime or the deconstruction of a particular structure of $\sin$. Rather, it is the ongoing witness to suffering, either in actuality or in memory, that perpetuates a conversion process of society to be vigilant against the misuse of cultural symbols or values for oppressive gain.

Only by ensuring that ongoing reflection and conversion is occurring will society ever have the opportunity to reach full liberative reconciliation. The task is enormous. It is surely out of reach in our time. But it is our moral obligation to seek it through the cooperation with the God who grants it.

\section{Conclusion}

The liberation of the oppressor is indeed the toughest task. It is difficult not only because it is seemingly beyond our nature to want to help those who hurt us, but because it is also challenging to pinpoint the problem - to find the hidden evil in the happy mask. But it is precisely because of this hiddenness that we ought not consider the liberation of the oppressor as a natural consequence of the liberation of the oppressed; some mechanical second step. Instead, we must consider the liberation of the oppressed a central aspect of liberative reconciliation that requires 
attention and not assumption. With this renewed focus on all parties, we are not undermining the preference for the victim-oppressed, but are actually serving the victim and God more broadly. We serve the victim by ensuring that we transform society and its structures in such a way that we are no longer waiting for the next evil to put on the mask, but instead are in an ongoing conversion to prevent the manipulation of our cultural symbols and values. And we serve God by respecting Jesus's teaching that even our enemies are our friends who deserve our love.

\section{Bibliography}

Alexander, Michelle. The New Jim Crow: Mass Incarceration in the Age of Colorblindness. New York: The New Press, 2010.

Freire, Paulo. Pedagogy of the Oppressed, rev. ed. New York: Continuum, 1993.

Gutíerrez, Gustavo. A Theology of Liberation. Maryknoll, N.Y.: Orbis Books, 1988.

Isenberg, Nancy. White Trash: The 400-Year Untold History of Class in America. New York: Penguin Books, 2016.

Moltmann, Jürgen. Experiences in Theology: Ways and Forms of Christian Theology. Minneapolis, MN: Fortress Press, 2000.

Moltmann, Jürgen and M. Douglas Meeks. "The Liberation of Oppressors.” In Christianity and Crisis. December 1978.

Reuther, Rosemary Radford. America, Amerikkka. Oakville, C.T.: Equinox, 2007.

Schreiter, Robert J. Reconciliation: Mission and Ministry in a Changing Social Order. Maryknoll, NY: Orbis Books, 1992.

Zehr, Howard. The Little Book of Restorative Justice, Revised and Updated. New York: Good Books, 2015. . A People's History of the United States: 1492-Present. New York: Perennial Classics, 2003. 